\title{
sciendo
}

DOI 10.2478/sbe-2019-0031

SBE no. 14(2) 2019

\section{FACTORS INFLUENCING CUSTOMERS' ATTITUDE TOWARDS SMS ADVERTISEMENT: EVIDENCE FROM MAURITIUS}

\author{
SANNEGADU RAJESH \\ International Business, University of Mauritius \\ GUNESH RAJ \\ Open University of Mauritius \\ SEETHIAH DHUVANDRANAND \\ Strategic Management and Entrepreneurship, University of Mauritius \\ DOOKHONY-RAMPHUL KIRAN \\ Tourism and Hospitality, University of Mauritius

\begin{abstract}
:
The purpose of this paper is to investigate factors influencing Mauritian consumers' attitude towards SMS advertising. Based on the Uses and Gratifications (U\&G) theory, a questionnaire was designed and administered among 277 University of Mauritius students using a survey method. Results showed a positive relationship between infotainment, credibility and SMS advertising value. Findings also revealed that advertising value had a positive impact on attitude towards SMS advertisement. Conversely, irritation had a negative relationship with the SMS advertising value. Therefore, marketing managers should present precise information to consumers in a pleasant and enjoyable way. Offensive, insulting and frustrating elements in SMS adverts that can irritate consumers should be avoided. These findings have managerial implications for marketing practitioners in creating and implementing effective SMS marketing campaigns to tap into the benefits of using mass advertising.
\end{abstract}

Key words: Uses and Gratifications (U\&G) theory, SMS advertising, advertising value, infotainment, credibility of advert

\section{Introduction}

Mobile technologies, facilitated by the increasing penetration of home Internet; affordable high speed broadband connections; expansion of social media platforms 
including Face book and the widespread consumer adoption of "smart" mobile devices, led to new market behaviours, interactions and experiences (Lamberton \& Stephen, 2016). On top of offering firms new ways of reaching, informing, engaging, selling to, learning about and providing service to customers, mobile technologies also changed the way buyers share information and interact with brands (Liu, Sinkovics, Pedzerka \& Haghirian, 2012). Moreover, the success and popularity of communicating short textual marketing messages through Short Messaging Service (SMS) has transformed mobile advertising into a new channel for advertising (Barwise \& Strong, 2002). Innovation in mobile technologies including Internet access through mobile phones also represents an interesting channel for transmitting advertising messages to consumers (Liu, Sinkovics, Pezderka \& Haghirian, 2012).

Mobile advertising have expanded exponentially over the years (Persaud \& Azhar, 2012). Bart, Stephen and Sarvary (2014) predicted that global spending on mobile advertising would exceed $\$ 62.8$ billion in 2017 compared to $\$ 16.7$ billion in 2013. To Taylor and Lee (2008) mobile marketing practices are likely to change rapidly as mobile technology continues to evolve. Therefore, to tap into the marketing opportunities that these technological advancements present to firms, mobile advertisers should develop customer centric strategies by understanding the factors influencing customers' attitude towards SMS advertisements.

Ever since the growth of mobile advertising, issues surrounding its application and acceptance have captured the interest and attention of both practitioners and academics (Vatanparast \& Butt, 2010). While earlier research explored consumers' initial acceptance of mobile advertising by applying the Technology Acceptance Model (TAM) (Davis et al. 1989), Theory of Reasoned Action (TRA) (Ajzen \& Fishbein 1980), or Theory of Planned Behaviour (Ajzen, 1991); subsequent studies such as Ducoffe (1995); Okazaki, Katsukura, and Nishiyama (2007); Petrovici and Marinov (2007) focused on identifying factors influencing consumers' attitudes towards mobile advertising. These theoretical developments contributed significantly in providing guidelines to digital advertisers to increase customers' response to mobile advertising. However, literature search revealed that studies on SMS advertisement are primarily carried out in developed countries while such studies in an island state like Mauritius is inexistent. For local businesses that face serious financial and marketing challenge, SMS advertising represents a considerable low cost option to reach a wide range of customers. Nevertheless, effective mobile communication strategies depend on an understanding of the factors influencing customers' attitudes towards SMS adverts. By identifying these factors, this study provides guidelines to digital advertisers in devising effective communication strategies. It also contributes to extant literature on mobile advertising by providing new insights on the factors influencing customers' attitude towards SMS advertisement in an island state like Mauritius.

\section{Objectives of the study}

The primary objective of the research is to explore the factors influencing customers' attitude towards SMS advertising in Mauritius. The main objectives of the study are outlined below: 
- to explore the extent to which infotainment of SMS advertisement influences customers' intention to seek further details on the products;

- to investigate the degree to which credibility of SMS advertisement is effective in motivating customers to follow up on the information;

- to examine if irritation of SMS advertisement affects customers' intention to respond to the advertisement.

\section{Literature Review}

\section{Mobile Advertising}

IMAP (2003) defines mobile advertising as the business of encouraging people to buy products and services using mobile channel as a medium to deliver the advertisement message. To Leppäniemi, Karjaluoto and Salo (2004), mobile advertising represents any paid message communicated by mobile media with the intent to influence the attitudes, intentions and behavior of those addressed by the commercial message. Mobile advertising therefore involves the use of mobile media to persuade/inform specific group of people about a firm's products and services. The most widely mobile media used to transmit commercial adverts remains the mobile phone and tablets (Duncan, Hazan \& Roche, 2014). Compared to the traditional marketing programs, mobile marketing is more beneficial for firms as it (i) provides a permanent connection with the consumers, (ii) helps to develop special offers to meet specific targets and (iii) helps in tailoring message to each customer based on his purchase history, demographic details and data usage (Berman, 2016).

With a total number of 1,650,000 mobile users in Mauritius (Statistics Mauritius, 2016), the potential for mobile advertising is huge and hence validating the importance of topic at issue. However, as the relative worth or utility of the advertising to consumer (Ducoffe, 1995:1) ensures effectiveness of mobile marketing, the advertising value represents a key concept in this study. This study will thus inform us if the advertising value is significant in developing a favourable or unfavourable attitude towards SMS advertising

\section{Theoretical Background and Hypothesis}

\section{Uses and Gratifications (U\&G) theory}

Initially developed in the 1940's to measure the effectiveness of the radio medium, the U\&G theory has, since then, been applied to explain the impact of various mass media such as television, electronic bulletins and wired Internet on the consumer's psychological motives and value generations (Luo 2002; Okazaki 2004; Stafford, Stafford \& Schkade, 2004). Typically, it seeks to explain and understand the psychological needs which shape people's reason for using the media and the reasons which motivate them to engage in certain media use behaviours for gratifications that fulfil their inherent needs (Rubin, 1994). It is considered as an audience-centered approach that focuses on what people do with media, as opposed to what media does to people (Katz, 1959). Two main principles underlie the U\&G theory firstly, individuals have a variety of motives for engaging in a 
particular media and secondly, the different needs and wants may influence one's media choice (Mahlangu, 2015). The selection and use of a particular communication media is often driven by the users' need for entertainment, escape, relaxation and the need to pass time (Katz, Blumler \& Gurevitch, 1973). Following the increasing use of technologies as promotional tools, the U\&G theory has been increasingly applied to identify the gratifications that users expect from these sophisticated means of communication. Its adequacy and robustness in understanding customers' motives in various media contexts have been ascertained in several studies including McCarty and Shrum (1993), Ferguson and Perse (2000) and Wei (2008) amongst others.

The most important and robust dimensions of the U\&G theory include informativeness, entertainment, credibility and irritation (Luo, 2002; Okazaki, 2004). Based on previous studies on Web advertising including Ducoffe (1995) and Stafford, Stafford \& Schkade, 2004), this study posits that the information and entertainment dimensions have an impact on SMS advertising value. Moreover, the present study integrates the informativeness and entertainment into one construct (infotainment) (Ducoffe, 1995; Liu, Sinkovics, Pedzerka \& Haghirian, 2012). The study further postulates that the credibility of the message is essential for customers to follow up on the information otherwise they will ignore the message (Okazaki, 2005). Finally, the study suggests that irritation in an advert adversely affect advertising value (Okazaki 2004). The proposed model is presented at Figure 1 and the impacts of each of these dimensions on the advertising value are discussed in the following sections.

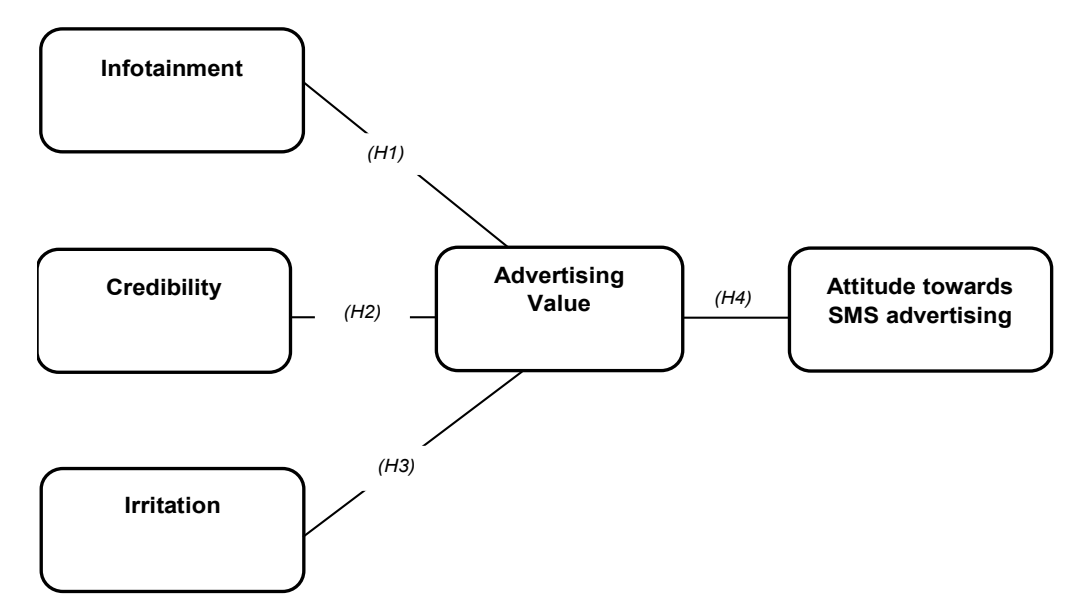

Figure 1: Diagram of Hypothesised Relationships

\section{Infotainment of SMS advertising}

The infotainment construct integrates the informativeness and entertainment constructs. Informativeness is the extent to which the advertisement provides consumers with resourceful, practical and helpful information (Ducoffe, 1995). Reflecting " $U$ " in the U\&G theory, information is considered as the need of the consumers (Ducoffe, 1995). If this need is fulfilled then it is likely that consumers change their perception into purchase 
intention (Aitken, Gray \& Lawson, 2008). While in general, marketers tend to send advertising message to potential customers, in the case of SMS advertising, customers prefer to obtain information to their own interests and that are relevant to them (Milne \& Gordon, 1993; Robins, 2003). On the other hand, the need for entertainment plays a major role in an individual's use of a communication media (Mahlangu, 2015). According to Katz et al. (1973), individuals tend to seek entertainment in a particular media to reduce anxiety, release tension and to cope with daily, boring and burdening situations. Entertainment reflects the " $G$ " dimension of the U\&G theory as it represents the feeling of humour, enjoyment and leisure (Xu, Oh \& Teo, 2009). Hence, customers are likely to respond positively to products that are advertised in a funny and entertaining way (Scharl, Dickinger \& Murphy, 2005) as an entertaining advertisement (i) is perceived more positively by the recipients and (ii) affects customer's perception on the value of the advertising (Chowdhury et al., 2006). Thus, given that the infotainment construct may have a positive association with the SMS advertising value, it is hypothesized that:

H1: Perceived Infotainment of SMS advertisement has a positive impact on advertising value.

\section{Credibility of SMS advertising}

Credibility refers to the customer's belief about the authenticity, integrity and reliability of advertisement (Chaudhry, et al. 2016). To Mac-Kenzie and Lutz (1989), the overall credibility of the advert is determined by both the advertiser's credibility and advertising's credibility. The advertiser's credibility represents his reputation, integrity and goodwill that determine the extent to which customers find the company to be a credible source of information (Okazaki, 2004). On the other hand, advertising credibility implies the core substance of the advertisement (Chaudhry et al., 2016) which is vital in a wireless communication as customers must make decisions or take actions on the basis of uncertain delivered information (Okazaki et al., 2007). The aforementioned arguments demonstrate that credibility positively affects the perceived value of advertising. Therefore;

H2: Credibility of SMS advertisement has a positive impact on advertising value.

\section{Irritation caused by SMS advertising}

Offensive, insulting and frustrating elements in advertisements sent to customers may be irritating and unwanted (Ducoffe, 1995). Due to the annoyance or irritation it causes, SMS advertising may lead to a general reduction of advertising effectiveness and the value perceived by audiences (Luo, 2002). Moreover, massive use of SMS advertising can confuse consumers such that the latter tend to delete advertising messages without reading (Chaudhry et al., 2016). Customers also perceive SMS advertising as either insecure (Siau \& Shen, 2003) or as an intrusion into their privacy (Stewart \& Pavlou, 2002). Based on these arguments, it is concluded that unwanted and incomprehensible SMS advertisements lead to irritation which reflect negatively on the perceived advertisement value. 
H3: The irritation felt from the unwanted and incomprehensible SMS advertisements negatively impact on the advertisement value.

\section{Perceived Advertising Value and Attitude towards SMS Advertising}

The value that consumers attach to the advertisement determine their actions, attitudes and judgements to the advertisement (Beatty et al., 1985). The advertising value is a reliable measure of the advertising effectiveness as it indicates the extent to which the customer is satisfied with the communication strategy of the organisation (Ducoffe, 1995). Liu, Sinkovics, Pedzerka and Haghirian (2012) consider the perceived value of advertising as the subjective evaluation of the worth or utility of advertising. Thus, a high value attached to the SMS advertisement can positively influence customers' attitude and convince them to accept it (Mehta, 2000). On the other hand, advertising that lacks value is more likely to have a negative effect that contributes to the formation of negative attitudes towards advertising (Ducoffe, 1996).

MacKenzie and Lutz (1989) define attitude as the consumers' mental approach that portrays his positive or negative responsiveness in relation to advertisement while Fishbein and Ajzen (1975) describe attitude as an individual's positive and negative feelings about performing the behaviour. Attitude towards an advertising has a major impact on consumers' behaviour (lacobucci \& Churchill, 2010). In the context of SMS advertising, the company deliberately exchanges information with the customers with a view to influence the latter's attitude about purchase decisions. "To the consumer, a successful exchange is judged by whether the advertising value itself can be considered to satisfy their expectations" (Liu, Sinkovics, Pedzerka \& Haghirian, 2012:25). Based on these arguments, it can be concluded that customers will have a positive attitude towards SMS advertising that have a high perceived advertising value.

H4: High perceived advertising value is positively associated with consumers' attitude towards SMS advertising.

\section{Research Methodology}

Adapted from Liu, Sinkovics, Pedzerka and Haghirian (2012), a questionnaire was developed to identify the factors influencing customers' attitude towards SMS advertisement. The questionnaire comprised of various sections which relate to the general use of SMS advertising and the factors influencing customers' general attitude towards SMS advertising. Using a five-point Likert scale (1= Strongly Disagree and 5= Strongly Agree), mobile phone users were requested to rate their perceptions on the factors influencing their reaction to SMS advertising. The data collection was conducted over a six weeks period and the interviewees were students from the largest university in the country. Prior to data collection, the questionnaire was pre tested among fifteen randomly chosen mobile owners and users, resulting in some minor changes of the wordings of some survey items such as the general attitude to mobile advertising and credibility of mobile advertising. Internal consistency and reliability of the scale was measured by the use of Cronbach's alpha (Hair et al., 2000). 


\section{Sampling Plan}

The target population consists of mobile phone owners and users. However, owing to the need for a relatively large sample size while keeping the research costs down, the sample size of this study amounted to 300 mobile phone owners and users. 277 questionnaires (92\%) provided usable answers for the investigation.

\section{Internal Consistency}

The Cronbach's overall value for the entire questionnaire (63 items) was 0.902 which indicates that the research instrument is a good indicator of what the researcher wants to investigate. According to Loewenthal (2001), a coefficient of 0.72 indicates a high level of reliability.

\section{Statistical Test}

Multiple linear regression analysis was conducted to determine the impact of the three independent constructs namely Infotainment (INF), Credibility (CRE) and Irritation (IRR) on value (VAL) of the SMS advertising. Seven main data assumptions were verified, namely identification of outliers, (absence of) multicollinearity, independence of residuals, normality of residuals, (absence of) heteroscedasticity, linearity and non-zero variances of the three independent variables. The reporting of assumption-checking results was carried out in the standard way as prescribed by Dart (2017). The sole purpose of carrying out multiple regression was to test the significance of the three predictors on $\mathrm{VAL}$, and not to establish a predictive model in the form of a structural equation. Moreover, a simple linear regression analysis was conducted to measure the impact of VAL (Advertising value to SMS recipients) on ATT (Attitude towards SMS advertising).

\section{Empirical Findings}

Table 1: Respondent's Profile

\begin{tabular}{|l|l|c|c|}
\hline & & $\mathbf{N}$ & $\mathbf{\%}$ \\
\hline Gender & Male & 83 & 30 \\
& Female & 194 & 70 \\
& Total & $\mathbf{2 7 7}$ & $\mathbf{1 0 0}$ \\
\hline Place of residence & Urban & 109 & 39.4 \\
& Rural & 107 & 38.6 \\
& Missing & 61 & 22 \\
& Total & $\mathbf{2 7 7}$ & $\mathbf{1 0 0}$ \\
\hline Age & $19-21$ & 97 & 35.0 \\
& $22-24$ & 115 & 41.5 \\
& +25 & 58 & 20.9 \\
& Missing & 7 & 2.5 \\
& Total & $\mathbf{2 7 7}$ & $\mathbf{1 0 0}$ \\
\hline Education & & $\mathbf{N}$ & $\mathbf{2}$ \\
& SC & 1 & .4 \\
& HSC & 35 & 12.6 \\
& Undergraduate & 197 & 71.1 \\
& Post Graduate & 39 & 14.1 \\
& Missing & 5 & 1.8 \\
& Total & $\mathbf{2 7 7}$ & $\mathbf{1 0 0}$ \\
\hline
\end{tabular}


Part A: Demographic Profile of the Respondents

Majority of the respondents $(70 \%)$ are female and $30 \%$ are male. Concerning the respondents' place of residence, $39.4 \%$ were from the urban region and $38.6 \%$ were from the rural area. As regards to the age classification of the respondents, $41.5 \%$ were between 22 and 24 years, followed by $35 \%$ between 19 to 21 years and $20.9 \%$ were above 25 years. With regards to the educational level, majority of the respondents $(71 \%)$ were registered as graduates, $14.1 \%$ were studying for a post grads and $12 \%$ have attained higher school certificate.

\section{Part A: Use of SMS and reaction to SMS Advertisement}

Majority of the respondents $(98 \%)$ use SMS as a means of communication. With regards to the frequency of SMS exchange, it is found that respondents send on average 9 SMS per day and they receive an average of 10 SMS daily. Concerning SMS adverts, $92 \%$ of the respondents stated that they receive on average 4 SMS adverts per week. It is also found that out of $92 \%(n=257)$ of the respondents who received SMS adverts, only $17 \%(n=44)$ reacted to these adverts while $5 \%(n=13)$ forwarded the advert to their friends. These findings suggest that many respondents do not consider mobile advertising as an important facility.

\section{Inferential Analysis- Correlation analysis}

A correlation analysis of the four research constructs was conducted using Pearson's product-moment correlation, since all the constructs were interval, after having been computed as the overall means of the ratings for the statements representing them. Table 1 below shows the results, including the means, standard deviations, as well as the reliability coefficients (Cronbach Alpha) in parentheses on the matrix diagonal.

Table 2: Bivariate Correlation Matrix

\begin{tabular}{|c|c|c|c|c|c|c|}
\hline Constructs & Mean & $S D$ & (1) & (2) & (3) & (4) \\
\hline (1) INF - Infotainment of SMS advertising & 3.07 & 0.57 & $(.84)$ & & & \\
\hline (2) IRR - Irritation involving SMS advertising & 2.97 & 0.61 & $-.22^{* *}$ & $(.58)$ & & \\
\hline (3) CRE - Credibility of SMS advertising & 2.94 & 0.61 & $.58^{* *}$ & $-.14^{*}$ & $(.61)$ & \\
\hline (4) VAL - Advertising value to SMS recipients & 3.08 & 0.72 & $.69^{* *}$ & $-.27^{\star \star}$ & $.59^{* *}$ & $(.65)$ \\
\hline
\end{tabular}

Results show that all the constructs were significantly correlated to one another at the $1 \%$ level, except for $C R E$ and IRR, which were significantly correlated at the $5 \%$ level. The most marked observation is that, IRR was significantly and negatively correlated to all the other constructs. The magnitudes of the reliability coefficients varied between 0.58 and 0.84 . Even though three of them were below the lower bound of 0.7 proposed by Cortina (1993), the results provided sufficient evidence to believe that each construct was relatively well-defined and exhibited reasonable unidimensionality (Ahmad, 2013). Moreover, it is expected that the inclusion of these three independent constructs in the multiple regression model (with VAL as dependent variable) would offer a valid model in terms of significance and predictive ability, as will be tested in the next section. 


\section{Multiple linear regression analysis}

Before running the multiple linear regression analysis, the following main data assumptions were verified to ensure that the estimated regression coefficients are the Best Linear Unbiased Estimates (BLUE), based on the Gauss-Markov theorem (Wooldridge, 2013:101).

\section{Identifying Outliers}

Table 2 shows the residuals statistics on running multiple regression for the fifth time in SPSS, whereby the magnitudes of all the standardised residuals were less than 3.29, i.e., acceptable. Prior to analysis, a final dataset of size was 272 .

Table 2: Residuals Statistics

\begin{tabular}{lrrrrr}
\hline & Minimum & Maximum & Mean & Std. Deviation & $N$ \\
\hline Predicted Value & 1.1194 & 4.5753 & 3.0784 & .52955 & 272 \\
Residual & -1.47500 & 1.39737 & .00000 & .48996 & 272 \\
Std. Predicted Value & -3.700 & 2.827 & .000 & 1.000 & 272 \\
Std. Residual & $\mathbf{- 2 . 9 9 4}$ & $\mathbf{2 . 8 3 6}$ & .000 & .994 & 272 \\
\hline
\end{tabular}

Dependent Variable: Advertising value to SMS recipients

Checking for multicollinearity

The absence of multicollinearity was confirmed by the figures in the last two columns of the SPSS Coefficients as shown in Table 3, since all tolerance values exceeded 0.2 and VIF figures were all less than 10 (Hair et al., 1998).

Table 3: Collinearity Statistics

\begin{tabular}{|c|c|c|c|c|c|}
\hline \multirow{2}{*}{ Model } & \multicolumn{2}{|c|}{ Unstandardized Coefficients } & \multirow{2}{*}{$\begin{array}{c}\text { Standardized } \\
\text { Coefficients } \\
\text { Beta }\end{array}$} & \multicolumn{2}{|c|}{ Collinearity Statistics } \\
\hline & B & Std. Error & & Tolerance & VIF \\
\hline (Constant) & .600 & .256 & & & \\
\hline INF & .629 & .066 & .496 & .641 & 1.559 \\
\hline IRR & -.145 & .050 & -.123 & .953 & 1.049 \\
\hline CRE & .333 & .061 & .281 & .659 & 1.517 \\
\hline
\end{tabular}

Dependent Variable: Advertising value to SMS recipients

Independence of residuals

The assumption of independence of errors was also met and autocorrelation was found to be insignificant, since a Durbin-Watson value of 2.169 was obtained (Table 4)

Table 4: Model Summary

\begin{tabular}{|c|c|c|c|c|c|c|c|}
\hline \multirow[t]{2}{*}{$R$} & \multirow[t]{2}{*}{$R$ Square } & \multirow{2}{*}{$\begin{array}{l}\text { Adjusted } R \\
\text { Square }\end{array}$} & \multirow{2}{*}{$\begin{array}{c}\text { Std. Error of the } \\
\text { Estimate }\end{array}$} & \multicolumn{3}{|c|}{ Change Statistics } & \multirow{2}{*}{$\begin{array}{l}\text { Durbin- } \\
\text { Watsor }\end{array}$} \\
\hline & & & & $\begin{array}{l}R \text { Square } \\
\text { Change }\end{array}$ & $F$ Change & $\begin{array}{l}\text { Sig. } F \\
\text { Change }\end{array}$ & \\
\hline $.734^{\mathrm{a}}$ & .539 & .534 & .49269 & .539 & 104.354 & .000 & 2.169 \\
\hline \multicolumn{8}{|c|}{ Predictors: (Constant), INF, IRR, CRE } \\
\hline \multicolumn{8}{|c|}{ Dependent Variable: Advertising value to SMS recipients } \\
\hline
\end{tabular}


The normality of residuals

The normality of residuals, which is a basic assumption of the regression model (Islam, 2011), was verified by visual inspection of the histogram of standardised residuals (Figure 2 A). From the normal curve drawn by SPSS, errors approximately followed a standard normal distribution, with a mean of $-3.96 \times 10^{-15}(S D=0.994)$. Normality was also confirmed by the corresponding normal $P-P$ plot of standardised residuals, which showed that all points were either on or very close to the line of norm (Figure 2 B).

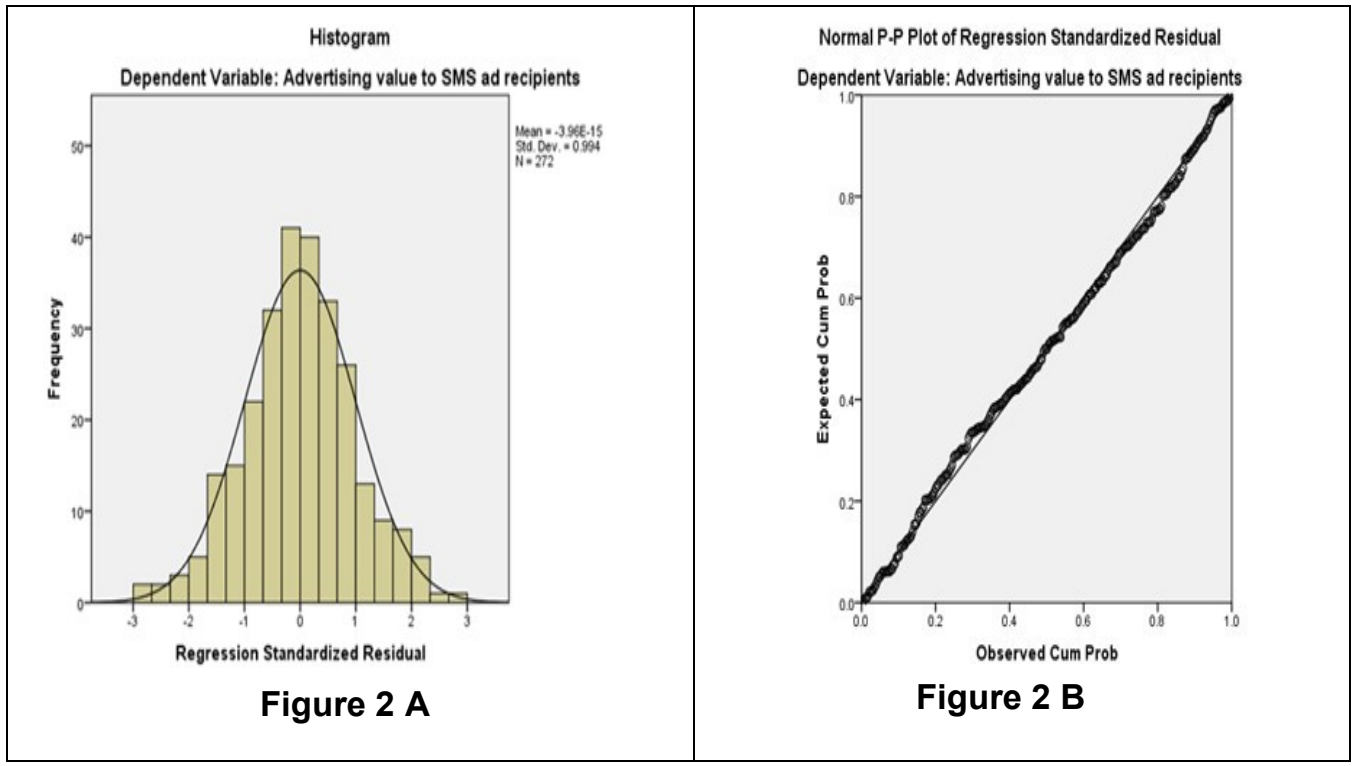

Detecting heteroscedasticity

There was also no sign of heteroscedasticity in the data, meaning that the variances along the line of best fit in the scatterplot did not experience any drastic changes, i.e., they remained very much homogenous throughout (Figure 3).

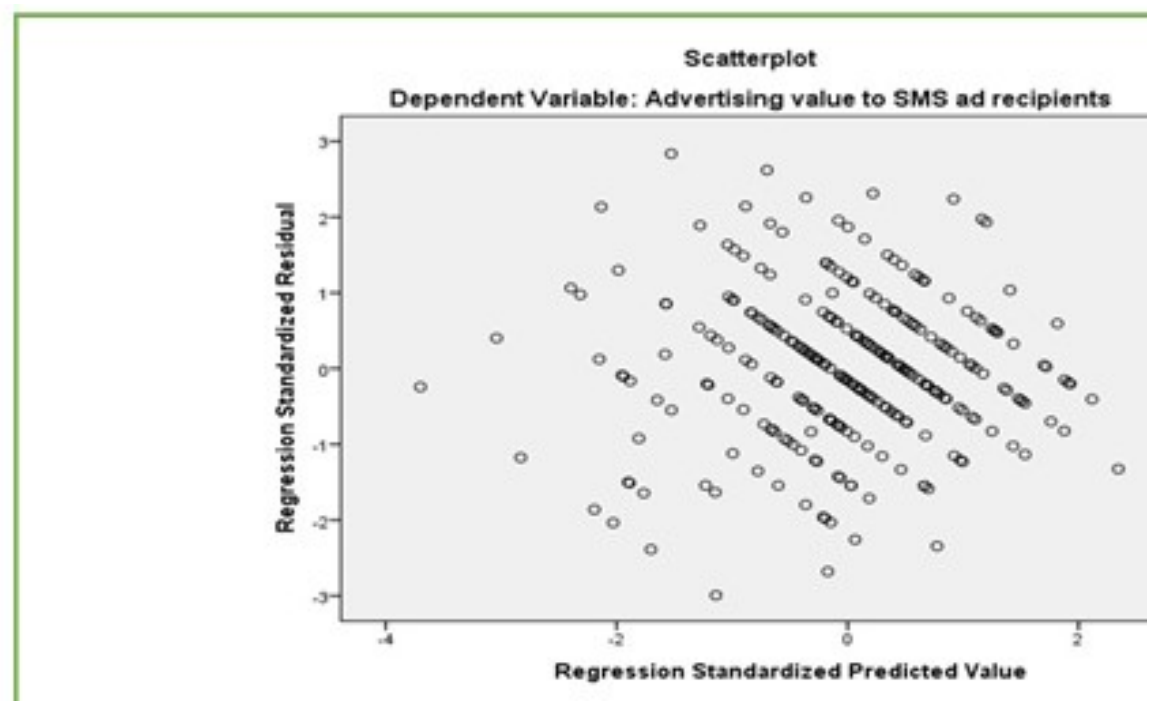


Linearity and non-zero variances

Table 5 below confirms that none of the predictors had zero variance.

Table 5: Non-zero variances of independent variables

\begin{tabular}{|l|c|c|}
\hline Predictors & Mean & Variance \\
\hline INF - Infotainment of SMS advertising & 3.0705 & .323 \\
\hline IRR - Irritation involving SMS advertising & 2.9730 & .374 \\
\hline CRE - Credibility of SMS advertising & 2.9415 & .371 \\
\hline
\end{tabular}

\section{Results of analysis}

The ANOVA table below was generated by SPSS for the regression model:

Table 6: ANOVA

\begin{tabular}{lcrccc}
\hline \multicolumn{1}{c}{ Model } & Sum of Squares & $d f$ & Mean Square & $F$ & Sig. \\
\hline Regression & 75.994 & 3 & 25.331 & 104.354 & .000 \\
Residual & 65.055 & 268 & .243 & & \\
Total & 141.049 & 271 & & & \\
\hline
\end{tabular}

Dependent Variable: Advertising value to SMS recipients

Predictors: (Constant), INF, IRR, CRE

The figures from Table $6(F(3,268)=104.354, p<0.001)$ confirmed that the regression model was significant in terms of predictability. The three predictors were then entered one at a time (as blocks) in a hierarchical regression model (regardless of the order) so as to obtain a model summary breakdown (Table 7), and hence determine their individual amount of shared variance with the dependent variable. It may be observed that they explained a fairly large amount of the shared variance $(53.9 \%)$ with the dependent variable $\left(R^{2}=.539, R^{2}\right.$ Adjusted $\left.=.534\right)$. The regression model may thus be classified as very good in terms of data fit.

Table 7: Model Summary

\begin{tabular}{cccccccc}
\hline Model & $R$ & $R$ Square Adjusted $R$ & Std. Error of the \\
Square & & Estimate & $\begin{array}{c}\text { Change Statistics } \\
\text { R Square } \\
\text { Change }\end{array}$ & $\begin{array}{c}\text { F Change } \\
\text { Sig. F } \\
\text { Change }\end{array}$ \\
\hline 1 & $.686^{\mathrm{a}}$ & .471 & .469 & .52561 & .471 & 240.563 & .000 \\
2 & $.698^{\mathrm{b}}$ & .487 & .483 & .51873 & .016 & 8.210 & .004 \\
3 & $.734^{\mathrm{c}}$ & .539 & .534 & .49269 & .052 & 30.180 & .000 \\
\hline
\end{tabular}

Predictors: (Constant), INF, IRR, CRE (in that order)

Dependent Variable: Advertising value to SMS recipients

All three predictors, namely INF $\left(R^{2}=.471, F=240.563, p<0.001\right), I R R\left(R^{2}=.016, F=\right.$ 8.210, $p=0.004)$ and $\operatorname{CRE}\left(R^{2}=.052, F=30.180, p<0.001\right)$ significantly explained the variability in $V A L$ at the $1 \%$ level, with INF explaining the major part of the shared variance (47.1\%). 
Table 8: Coefficients

\begin{tabular}{lccccc}
\hline & \multicolumn{2}{c}{ Unstandardized Coefficients } & $\begin{array}{c}\text { Standardized } \\
\text { Coefficients } \\
\text { Beta }\end{array}$ & $t$ & Sig. \\
\hline (Constant) & Std. Error & .256 & & 2.347 & .020 \\
INF & .600 & .066 & .496 & 9.574 & .000 \\
IRR & .629 & .050 & -.123 & -2.904 & .004 \\
CRE & -.145 & .061 & .281 & 5.494 & .000 \\
\hline
\end{tabular}

a. Dependent Variable: Advertising value to SMS recipients

Table 8 revealed that all three predictors significantly impacted on $V A L$ at the $1 \%$ level: $\operatorname{INF}(\beta=.496, t(268)=9.574, p<0.001), \operatorname{IRR}(\beta=-.123, t(268)=-2.904, p=0.004)$ and CRE $(\beta=.281, t(268)=5.494, p<0.001)$. While IRR impacted negatively on VAL, the most influential factor revealed to be INF (highest beta coefficient of .496). Thus, $\boldsymbol{H}_{\mathbf{1}}, \boldsymbol{H}_{\mathbf{2}}$ and $\boldsymbol{H}_{3}$ were all accepted at the $1 \%$ level.

Testing the Impact of Advertising Value on Attitude towards SMS advertising

Simple linear regression analysis was conducted to test $\boldsymbol{H}_{\mathbf{4}}$, i.e., the impact of $V A L$ (Advertising value to SMS recipients) on ATT (Attitude towards SMS advertising).

Table 9: Model Summary

\begin{tabular}{ccccccc}
\hline$R$ & $R$ Square & $\begin{array}{c}\text { Adjusted } R \\
\text { Square }\end{array}$ & $\begin{array}{c}\text { Std. Error of the } \\
\text { Estimate }\end{array}$ & $\begin{array}{c}\text { Change Statistics } \\
\text { R Square } \\
\text { Change }\end{array}$ & $\begin{array}{c}\text { F Change } \\
\text { Sig. F Change }\end{array}$ \\
\hline $.455^{\mathrm{a}}$ & .207 & .204 & .67093 & .207 & 71.718 & .000 \\
\hline
\end{tabular}

Predictors: (Constant), Advertising value to SMS recipients

Dependent Variable: Attitude towards SMS advertising

The regression model was significant: $F(1,275)=71.718, p<0.001$, DW-statistic $=2.018$ whereby Advertising value to SMS recipients explained $20.7 \%$ of the variability in Attitude towards SMS advertising.

Table 10: Coefficients

\begin{tabular}{lccccc}
\hline & \multicolumn{2}{c}{$\begin{array}{c}\text { Unstandardized } \\
\text { Coefficients }\end{array}$} & Standardized & $t$ & Sig. \\
& $\mathrm{B}$ & Std. Error & Beta & & \\
\hline (Constant) & 1.144 & .171 & & 6.674 & .000 \\
Advertising value to SMS recipients & .459 & .054 & .455 & 8.469 & .000 \\
\hline
\end{tabular}

Dependent Variable: Attitude towards SMS advertising

The table of coefficients confirmed the significance of the impact of Advertising value to SMS recipients $(\beta=.455, t(275)=8.469, p<.001)$ on Attitude towards SMS advertising at the $1 \%$ level. Therefore, $\boldsymbol{H}_{\mathbf{4}}$ was confirmed, i.e., Advertising value to SMS recipients has a positive and significant impact on Attitude towards SMS advertising. 


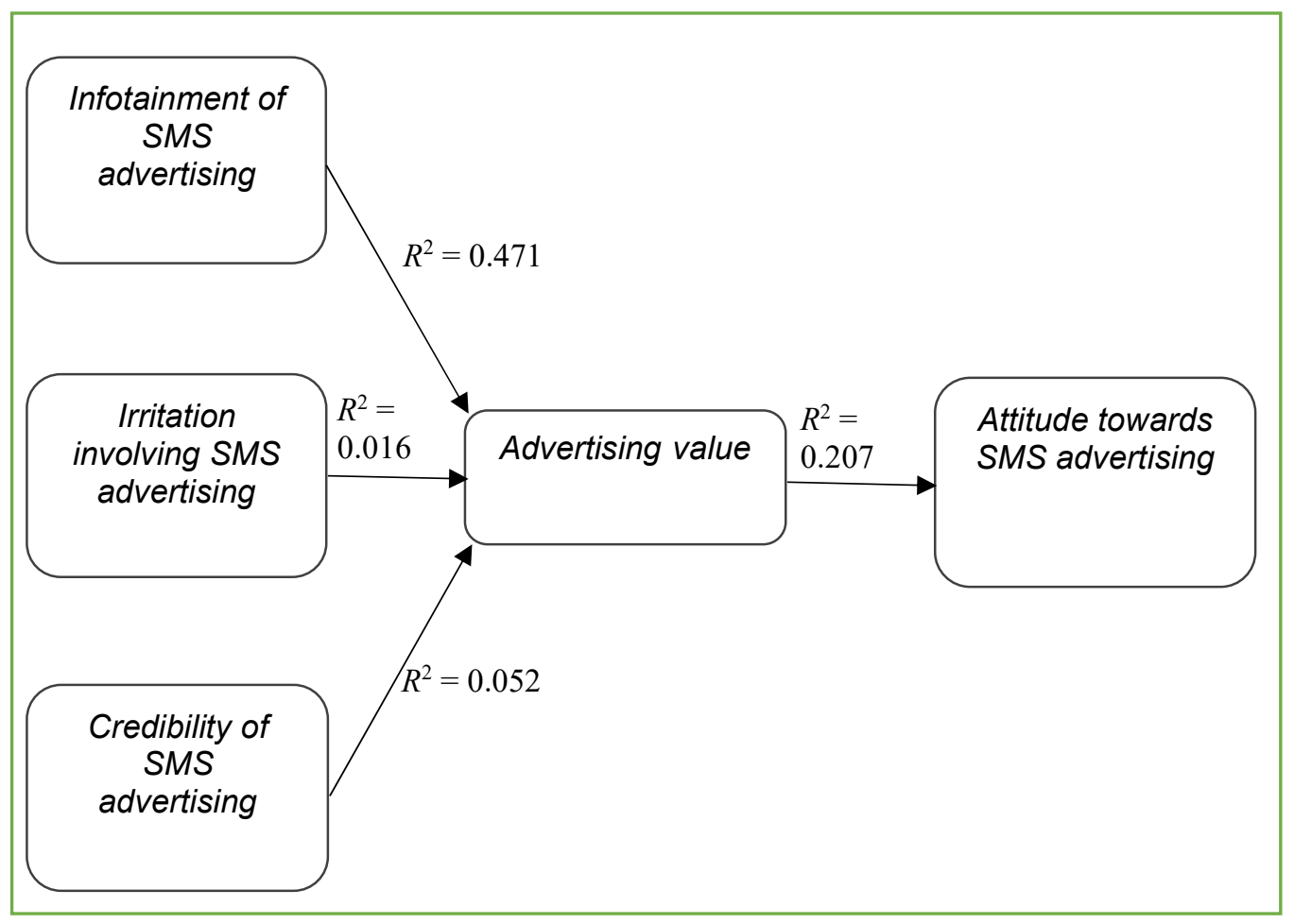

\section{Discussion of the Findings}

This study contributes to the understanding of the impact of infotainment, irritation and credibility on the perceived value of advertising amongst consumers in Mauritius. Empirical results have shown that infotainment, irritation and credibility are key factors predicting the perceived value of advertising. The implications of the relationships between constructs are discussed in the following paragraphs.

H1: Infotainment of SMS advertising impacts significantly and positively on advertising value to SMS recipients.

Results demonstrate that infotainment significantly influences perceived advertisement value. These results correspond to Liu, Sinkovics, Pedzerka and Haghirian's (2012) and Mahlangu's (2015) studies which present infotainment as a predictor for perceived advertising value. This implies that respondents attached value to SMS adverts that contain a combination of information and entertainment. One of the core functions of advertising is to provide information to influence purchase intention (Aitken, Gray \& Lawson, 2008). Therefore, companies should ensure that SMS adverts consist of information that are pertinent and useful to the recipient. Moreover, businesses should include an entertainment element within an advert to establish an emotional link with customers that may positively affect their perception on the value of the advert (Chowdhury et al. 2006; Mahlangu, 2015). 
H2: Irritation involving SMS advertising impacts significantly and negatively on advertising value to SMS recipients.

Findings also show that irritating SMS adverts tend to be perceived negatively by customers. These findings are congruent to existing literature which suggests that irritation and annoyance in SMS advertisement can lead to a general reduction of advertising effectiveness and in the value perceived by audience (Luo, 2002). While in many cases, customers' consent are sought prior to sending SMS adverts, firms also send unsolicited SMS adverts to inform customers about their products/service. In the latter case, marketers assume that the advertising message sent via mobile devices will be read and remembered. However, customers may find SMS adverts annoying, irritating and unwanted if they are not of interest to them. Unsolicited SMS adverts can be perceived as an intrusion into customers' privacy (Stewart \& Pavlou, 2002). Customers, thus, tend to delete unsolicited messages and allocate a negative perception to brands (Chaudhry et al., 2016).

H3. Credibility of SMS advertising impacts significantly and positively on advertising value to SMS recipients.

Results display a significant relationship between the credibility of SMS advert and advertising value $(F=30.180)$. This implies that consumers tend to have favourable perceptions about the value of the advertising when they believe that the SMS advert is credible and trustworthy. This result seems to be consistent with existing research such as Brackett and Carr (2001); Okazaki (2004); Okazaki, Katsukura, and Nishiyama (2007) which describe credibility as an important antecedent of advertising value.

H4. Advertising value to SMS recipients impacts significantly and positively on attitude towards SMS advertising.

Results also reveal that the perceived value of SMS advertising positively and significantly predicts customers' attitudes towards SMS advertising in Mauritius. These findings imply that customers' attitude towards SMS advertising is largely dependent on how they perceive the advertisement value. If consumers highly rate advertising value then they are more likely to have favorable attitudes towards the advertisements and vice versa. This result tallies with extant literature on consumer's attitudes to advertising such as Tsang, Ho, and Liang (2004); Petrovici and Marinov (2007) and Lin, Zhou and Chen (2014) amongst others.

\section{Managerial Implications and Recommendations}

SMS advertisements as a low-cost e-marketing strategies to reach a wide number of consumers are being increasingly used by companies in Mauritius. However, assuming that consumers will react directly or indirectly to SMS advertisements may be proved to be a wrong premise. Thus, the results of this study present an opportunity to better understand (i) customers' perceptions towards SMS advertisement in Mauritius and (ii) the factors predicting the perceived value of the advertisements so that policy makers, advertising agencies and companies formulate effective mobile marketing communication 
strategies. The next paragraph presents strategies to increase advertising value so that customers develop a positive attitude towards SMS adverts.

Companies should send accurate, timely and useful information to targeted group of consumers depending on their interests, needs and wants. Adverts should be designed in such a way that they effectively catch the audience's attention. Furthermore, to add to the value to the SMS adverts and to make them more appealing, businesses should add humorous features to the messages as customers tend remember for much longer humorous advertisements (Barber, 2015). Moreover, businesses should send adverts only to customers who have given their consent to receive promotional information as customers tend to (i) ignore unsolicited SMS adverts and (ii) allocate a negative perception to brand (Chaudhry, et al., 2016). Furthermore, marketers should not send SMS adverts too often or at inappropriate times as this may be perceived as an intrusion into the customer's life and privacy. To establish customer-client relationships, marketers should develop communication strategies such that consumers perceive the company as a trusted source of information. To ensure credibility of the advert, marketers should provide customers with precise information that they desire and not information that they may interpret as spam. Credibility of the advertisers can be ascertained by delegating the responsibility of sending out SMS advertisement to dedicated advertising agencies.

\section{Conclusion, Limitations and direction for future research}

This study aimed at investigating the factors influencing customers' attitude towards SMS advertising. Findings of the study indicate that infotainment and credibility have a positive influence on customers' attitudes towards SMS advertisement. Conversely, it has been found that irritation negatively influences customers' attitude towards SMS advertisement. Based on the findings of the study, strategies to make SMS advertisements informative, likeable, enjoyable, credible and trust worthy have been proposed. These recommendations will guide companies, wireless marketers and marketing agencies in designing effective SMS marketing strategies.

\section{Limitations of the study}

As with all studies, this study also has its own limitations which can narrow down scope of the conclusions. The first limitation is derived from the geographical location of the current research (i.e. Mauritius) and its application to other economies similar to Mauritius. While it is believed that the findings may be applicable to economies that share common demographic characteristics with Mauritius; they may not be necessarily relevant to economies that are not on the same level of socio-economic and technological development as Mauritius. Therefore, one should be cautious about making causal interpretations of these findings. Secondly, there is the possibility that the current study might not have fully captured all the aspects of the current market given that the mobile technology is rapidly evolving. Thirdly, the fact that the population comprised of university students, generalisation of the findings may pose certain problems. Fourthly, given that this cross-sectional study represents a single point in time, it does not demonstrate how customers' attitude and behaviour towards SMS advertisement may change over time. 
Finally, the study is based on the customer's perspective only and the underlying perceptions of the companies, marketing agencies and marketing professionals have not yet been explored.

\section{Future Research}

In this respect, further research is needed in order to enhance the understanding the factors influencing customers' attitude towards SMS advertisement in economies like Mauritius. To keep pace with the changes in technology, supplementary research can be conducted to identify other factors including trust, demographic factors and environmental characteristics that can potentially affect customers' attitude towards SMS advertisements. Further studies employing a longitudinal approach can be undertaken to ascertain any change in customers' attitude and behaviour towards SMS advertisements. Also, given the uniqueness of each country, future research can consider other possible factors including culture that could serve as potential antecedents of customers' attitude towards SMS advertisement. Further studies in different countries sharing similar characteristics with Mauritius would most likely strengthen and validate the findings of this exploratory study. It is also important that the future research include a broader range of mobile consumers. Finally, future studies can explore how companies, marketing agencies and marketing professionals use SMS marketing to reach their target audience.

\section{Reference}

Ahmad, N. S. A. (2013), "Assessing the unidimensionality, reliability, validity and fitness of influential factors of 8th grades student's Mathematics achievement in Malaysia", International Journal of Advanced Research, Vol 1, Iss 2, pp. 1-7.

Aitken, R., Gray, B. and Lawson, R. (2008) "Advertising effectiveness from a consumer perspective", International Journal of Advertising, Vol.27, Iss.2, pp279-297

Ajzen, I. (1991), "The theory of planned behavior", Organizational Behavior and Human Decision Processes, Vol. 50, Iss.2, pp 179-211

Ajzen, I., \& Fishbein, M. (1980), Understanding attitudes and predicting social behavior. Englewood Cliffs, NJ: Prentice-Hall

Barber, H. (2015), "How to Use Humour Effectively in Your Text Marketing Efforts?" Available online at https://www.firetext.co.uk/blog/how-to-use-humour-effectively-in-your-text-marketingefforts/

Bart, Y., Stephen, A.T. and Sarvary, M. (2014), "Which Products Are Best Suited to Mobile Advertising? A Field Study of Mobile Display Advertising Effects on Consumer Attitudes and Intentions", Journal of Marketing Research, Vol. 51, Iss. 3, pp. 270-285

Barwise, P. and Strong, C. (2002), "Permission based mobile advertising", Journal of Interactive Marketing, Vol. 16, Iss.1, pp.14-24

Beatty, S.E., Kahle, L.R., Homer, P. and Shekar, M. (1985), "Alternative Measurement Approaches to Consumer Values: The List of Values and the Rokeach Value Survey," Psychology and Marketing, Vol.2, Iss.3, pp.181-200

Berman, B. (2016), "Planning and implementing effective mobile marketing programs", Business Horizons, Vol. 59, pp. 431-439

Brackett, L. K. and Carr, B. N. (2001), "Cyberspace Advertising vs. Other Media: Consumer vs. Mature Student Attitudes", Journal of Advertising Research, Vol 41, Iss. 5 pp.23-33 
Chaudhry, N.I, Bilal, A. and Rasool, Z. (2016), "Influencing the attitude towards SMS advertisement: An empirical study in Pakistan", Pakistan Business Review

Chowdhury, H.K, Parvin, N., Weitenberner, C. and Becker, M. (2006), "Consumer Attitude toward Mobile Advertising in an Emerging Market: An Empirical Study," International Journal of Mobile Marketing, Vol. 1, Iss.2, pp. 33-41

Cortina, J. M. (1993), "What is coefficient alpha? An examination of theory and applications", The Journal of Applied Psychology. Vol. 78, Iss. 1, pp 8-104. Retrieved from: doi: 10.1037/00219010.78.1.98

Dart, A. (2017) Reporting Multiple Regressions in APA - Part One, Available online at http://www.adart.myzen.co.uk/reporting-multiple-regressions-in-apa-format-part-one/

Davis, F. D., Bagozzi, R. P., \& Warshaw, P. R. (1989), "User acceptance of computer technology: A comparison of two theoretical models", Management Science, Vol. 35 Iss. 8, pp.982-1003

Ducoffe, R.H. (1995), "How Consumers Assess the Value of Advertising?", Journal of Current Issues \& Research in Advertising, Vol.17, Iss 1., pp.1-18

Duncan, E., Hazan, E., and Roche, K. (2014). Digital disruption: Six consumer trends and what businesses need to do now McKinsey \& Company Available online at http://www.mckinseyonmarketingandsales.com/digital-disruption-evolving-usage-and-thenew-value-chain

Ferguson, D.A. and Perse, E.M. (2000), "The World Wide Web as a functional alternative to television” Journal of Broadcasting \& Electronic Media, Vol.44, Iss. 2 pp.155-174.

Field, A. P. (2013) Discovering statistics using IBM SPSS Statistics: And sex and drugs and rock 'n' roll. 4th ed. London, Sage.

Fishbein, M., and Ajzen, I. (1975), "Belief, attitude, intention \& behaviour: an introduction to theory \& research", Addison-Wesley, California.

Hair, J. F., Tatham R. L., Anderson R. E. \& Black W. (1998) Multivariate data analysis. 5th ed. Englewood Cliffs, NJ, Prentice Hall.

Hair, J.F., Bush, R.P. and Ortinau, D.J. (2000), Marketing Research: A Practical Approach for the New Millennium, McGraw-Hill, New York, NY.

lacobucci, D. and Churchill, G.A. (2010), Marketing Research: Methodological Foundations. 10th ed. Mason, Ohio: South-Western Cengage Learning.

IMAP Project (2003), "Global System Framework - Business Model, Research Report, Available online at http://www.imapproject.org/imapproject/downloadroot/public1/D2.1.b\%206\%2002\%2003.pdf

Islam, T. U. (2011)," Normality Testing - A New Direction. International Journal of Business and Social Science", Vol. 2, Iss 3, pp. 115-118.

Katz, E. (1959), "Mass communication research \& the study of culture", Studies in Public Communication, Vol.2, Iss.1 pp.1-6

Katz, E., Blumler, J.G. and Gurevitch, M. (1973), "Uses and gratifications research", Public Opinion Quarterly, Vol. 37, Iss 4, pp. 509-523

Lamberton, C. and Stephen, A.T. (2016), "A Thematic Exploration of Digital, Social Media, and Mobile Marketing: Research Evolution from 2000 to 2015 and an Agenda for Future Inquiry," Journal of Marketing, Vol. 80, Iss.6, pp. 146-172.

Leppäniemi, M, Karjaluoto, H. and Salo, J. (2004), "The Success Factors of Mobile advertising Value Chain", E-Business Review, Vol. IV, pp.93-97.

Lin, H., Zhou, X., \& Chen, Z. (2014), "Impact of the content characteristics of short message service advertising on consumer attitudes", Social Behavior and Personality: An international Journal, Vol. 42, pp. 1409-1420

Liu, C.L., Sinkovics, R.R., Pedzerka, N. and Haghirian, P. (2012), "Determinants of Consumer Perception towards Mobile advertising”, Journal of Interactive Marketing, Vol.26, pp. 21-32 
Loewenthal, K.M. (2004), "An introduction to psychological tests and scales", Psychology Press Luo, X. (2002), "Uses and Gratifications Theory and E-Consumer Behaviors: A Structural Equation Modelling Study," Journal of Interactive Advertising, Vol.2 Iss.2 pp 34-41.

MacKenzie, S. B., and Lutz, R. J. (1989), "An empirical examination of the structural antecedents of attitude toward the ad in an advertising pretesting context", The Journal of Marketing, pp.48-65

Mahlangu, H.B. (2015), "The applicability of uses and gratifications theory in predicting Facebook game playing", African Journal for Physical, Health Education, Recreation and Dance, (AJPHERD) Vol. 21, Iss:1 pp. 162-172.

McCarty, J.A. \& Shrum, L.J. (1993), "The role of personal values and demographics in predicting television viewing behaviour", Journal of Direct Marketing, Vol. 22, Iss. 4, pp.77-101.

Mehta, A. (2000), "Advertising attitudes and advertising effectiveness", Journal of Advertising Research, Vol. 40, Iss. 3, pp 67-71.

Milne, G.R. and Gordon, M.E (1993), "Direct Mail Privacy-Efficiency Trade-Offs within an Implied Social Contract Framework," Journal of Public Policy \& Marketing, Vol. 12, Iss. 2, pp. 206215

Okazaki, S. (2004), "How Do Japanese Consumers Perceive Wireless Ads? A Multivariate Analysis," International Journal of Advertising, Vol.23, Iss 4, pp.429-454.

Okazaki, S (2005), "External Search, Content Credibility and Intrinsic Gratifiers Influencing Attitude toward Wireless Ads," Asia Pacific Advances in Consumer Research, Vol. 6, Iss.7, pp.5-12

Okazaki, S., Katsukura, A. and Nishiyama, M. (2007), "How Mobile Advertising Works: The Role of Trust in Improving Attitudes and Recall," Journal of Advertising Research, Vol. 47, Iss. 2.

Persaud, A. and Azhar, I. (2012), "Innovative mobile marketing via smartphones: Are consumers ready?", Marketing Intelligence \& Planning, Vol. 30 Iss: 4, pp.418-443

Petrovici, D. and Marinov, M. (2007), "Determinants and Antecedents of General Attitudes towards Advertising: A Study of Two EU Accession Countries," European Journal of Marketing, Vol.41, Iss. 3, pp.307-26.

Robins, F. (2003), "The Marketing of 3G," Marketing Intelligence \& Planning, Vol.21, Iss.6, pp 370378.

Rubin, A. M. (1994), "An examination of television viewing motives", Journal of Communication, Vol. 8, Iss. 3 pp.141-165

Scharl, A., Dickinger, A. and Murphy, J. (2005), "Diffusion and success factors of mobile marketing", Journal Electronic Commerce Research and Applications, Vol.4, Iss.2, pp. 159-173

Siau, K. and Shen, Z. (2003), "Building Customer Trust in Mobile Commerce," Communications of the ACM, Vol. 46, Iss.4, pp.91-94.

Stafford,T.F, Stafford, M.R. and Schkade, L.L (2004), "Determining Uses and Gratifications for the Internet", Decision Sciences, Vol.35, Iss.2 pp.259-288

Statistics Mauritius (2016), Social and Economic Indicators, Available online at http://statsmauritius.govmu.org/English/Publications/Pages/Economic-and-SocialIndicators.aspx

Stewart, D. and Pavlou, P. (2002), "From Consumer Response to Active Consumer: Measuring the Effectiveness of Interactive Media," Journal of the Academy of Marketing Science, Vol.30, Iss.4, pp.376-396.

Taylor, C.R. and Lee, D.H. (2008), Introduction: New media: Mobile advertising and marketing, Psychology and Marketing, Vol.25, Iss.8, pp. 711-713

Tsang, M.M., Ho, S.C and Liang, T.P. (2004), "Consumer attitude towards mobile advertising: An empirical study", International Journal of Electronic Commerce, Vol.8, Iss.3 pp. 65-78

Vatanparast, R. and Butt, A.H. (2010), "An empirical study of factors affecting the use of mobile advertising”, International Journal of Mobile Advertising, Vol. 5, Iss. 1, pp.28-40 
Wei, R. (2008), "Motivations for using the mobile phone for mass communications and entertainment", Telematics and Informatics, Vol.25 pp.36-46.

Woolridge, J. M. (2013) Introductory Econometrics: A Modern Approach. 5th ed. Mason, OH, SouthWestern Cengage Learning

Xu, H., Oh, L.B., and Teo, H.H. (2009), "Perceived effectiveness of text vs. multimedia locationbased advertising messaging", International Journal of Mobile Communications, Vol. 7, Iss. 2, pp. 154-177. 